\title{
Malicious Envy : Its Correlation with Self-Concept and Gratitude
}

\author{
Nikmah Rochmawati \\ Universitas Islam Negeri Walisongo Semarang \\ \{rahma_mewangi@walisongo.ac.id\}
}

\begin{abstract}
Malicious envy is a part of the negative emotions which is a psychopathological disease. If it is allowed, it will endanger one's happiness and interpersonal relationships. This study aims to test empirically the role of self concept and gratitude for malicious envy among students of UIN Walisongo Semarang. Subjects in this study were 329 students taken using a cluster sampling technique. The measurement instrument was the self concept scale, Islamic gratitude scale and malicious envy scale. Data analysis using multiple linear regression 2 predictors analysis shows that self concept and gratitude can be used as indicators to predict the malicious envy among college students positively and very significantly or $\mathrm{p}<0.01$. Minor hypothesis shows that self concept can not predict the emergence of malicious envy among college students, but the gratitude can predict to the emergence of malicious envy among college students positively and very significantly or $\mathrm{p}<0.01$.
\end{abstract}

Keywords: Envy; Hasad; Self-Concept; Gratitude; Happiness

\section{Introduction}

As a part of negative emotions which is a psychological and psychopathological disease [1], it is very important to find the causes of malicious envy to achieve individual and social happiness. An envious person is never happy, easily sad, anxious as they always feel dissatisfied with what they have, and compares it with others [2]. They like to gossip, criticize, cannot introspect, lie, are arrogant, easily provoked by emotions and used, and even want to do corruption, steal, etc. Envy or hasad in Arabic is a feeling of dislike of the blessings gotten by others, wanting them to disappear, and the desire to have the pleasures that others have [3].

The preliminary study on 45 students of the Faculty of Psychology and Health at UIN Walisongo Semarang on May 18-20, 2020 found that they often feel frustrated when their friends, neighbors, or siblings have more goods, achievements, and beauty. This finding is interesting to research because students are future national leaders who will be responsible for the future sustainability of the nation and they are at the post-conventional stage in the age of moral development and the stage of formal operational cognitive development. This study is very important to conduct because studies focusing on the causes of malicious envy is still very rare. Therefore, this study seeks to find the causes for malicious envy in students which can eventually be used as a reference to overcome the emergence of malicious envy and design character education. This study aims to empirically examine the role of self-concept 
and gratitude for malicious envy in students of the Faculty of Psychology and Health, UIN Walisongo Semarang.

"Envy" is derived from the Latin invidere, which means "to see others with hatred," causing someone to have bad intentions and hostility towards the person he hates [4]. Envy is the pain suffered when seeing the luck and good fortune of others [5]. The social comparison by an envious person is an upward social comparison, instead of downward [6]. An envious person always involves ego and believes as well as feels that he needs and deserves what others have [7]. Envy is an emotion that arises when someone feels defeated or lacking in superiority, achievement, ownership of something good compared to others, and hopes that they do not own it [8].

Malicious envy consists of three aspects, namely feelings, appraisals, and action tendencies [6]. The other aspects of malicious envy include dislike and the desire for the loss of other people's favors [9]. Malicious envy is caused by several factors. The first is a lack of gratitude, an individual's inability to be grateful for all the gifts of God [10]. People who are grateful for all the gifts of God may not be exposed to malicious envy [9] while people who have feelings of envy will never feel happy as they cannot be grateful for what they already have [11]. They always compare their own with that of others, making them easily get agitated and grieved [5]. If they cannot control themselves, they will do anything to get what they want and harm those they do not like.

Gratitude is an emotion that arises after receiving a favor or gift which is valuable, precious, and altruistic [12]. The important aspects of gratitude are appreciation and recognition [13]. Fitzgerald explains that gratitude has three components, (a) a sense of appreciation for someone or something received, (b) having goodwill towards others, and (c) being a good person [14]. Watkins et al. also found four characteristics of people who have gratitude, including (a) always feeling sufficient, (b) recognizing and appreciating the contributions of others to them, (c) feeling and appreciating simple pleasures (breathing, health, etc.), and (d) realizing the urgency of expressing gratitude [15]. Listiyandini summarizes these components into three points, namely Having a sense of appreciation for others, God, and life, positive feelings towards one's life, and the tendency to act positively as an expression of positive feelings and appreciation [16]. In the Islamic concept, gratitude must be manifested in 3 aspects of behavior (gratitude with the heart, mouth, and deeds). Thus, in Islam, gratitude must involve cognition, affection, and action.

The second cause of malicious envy is low self-concept, an individual's perception of himself. Self-concept is a person's basic concept about himself, his opinions and thoughts, self-understanding and self-awareness, self-image compared with others, and the idealism developed. Someone who has a high self concept will accept their condition positively[17]. Individuals who have low academic self-esteem show hostility because of their envy towards others [10]. People who have a positive perception of themselves will not be exposed to malicious envy [18]. People with low self-concept cannot see their strengths and weaknesses due to their inability to provide a specific self-evaluation [1]. The components of self-concept are academic, non-academic, and general [19].

\section{The Present Research}

This study aims to empirically examine the role of self-concept and gratitude for malicious envy in students of the Faculty of Psychology and Health, UIN Walisongo Semarang. The major hypothesis in this study is that the variables of self-concept and gratitude are negative 
predictors for malicious envy simultaneously. The minor hypothesis is that self-concept and gratitude are the negative predictors for malicious envy.

\section{Method}

A total of 329 students of the Faculty of Psychology and Health were involved as the subjects selected using cluster random sampling. The independent variables in this study are self-concept and gratitude revealed by the self-concept and gratitude scales, respectively. The dependent variable is malicious Envy revealed by the malicious envy scale. Each scale consists of favorable and unfavorable items with four answer choices.

The self-concept scale, consisting of 26 items (13 favorable and 13 unfavorable items), is adapted from the self-concept scale by Prasetyo Budi Widodo which refers to Herberth W's concept. This study adapted Prasetyo Budi Widodo's self-concept scale, developed by Herberth W. Marsh from Self-Concept Enhancement and Learning Facilitation (SELF) Research Center, University of Western Sydney [20]. This self-concept theory consists of 3 aspects (academic, non-academic, self-esteem in general.

The gratitude scale, consisting of 26 items (13 favorable and 17 unfavorable items) is adopted from the Islamic Gratitude scale by Rochmawati based on Walkins and Fitzgerald's constructs which consist of three aspects (sense of appreciation, positive feelings towards one's life, and the tendency to act as an expression of positive feelings and appreciation) [21], integrated with the concept of gratitude from Al Ghazali which includes cognition, affection, and action [9].

The malicious envy scale, consisting of 25 items (13 favorable and 12 unfavorable items) is adopted from the envy scale by Rochmawati based on Van de ven's theory, namely feelings, appraisals, and action tendencies and integrated with the concept of malicious envy by AlGhazali, which is dislike and a desire for the loss of other people's favors [22].

Estimation of validity was conducted using the corrected Pearson's correlation technique with the lowest limit of the correlation coefficient of 0.30. Estimation of reliability was conducted using the internal consistency technique of Cronbach's Alpha with the lowest limit of 0.6. Multiple linear regression analysis with two predictors and a significance level of $p<$ 0.05 was used. The assumption test carried out was the normality test using the Kolmogorov Smirnov- $Z$ with the normality principle with $p>0.05$ and the linearity test using the deviation from linearity principle with $p>0.05$ or if the linearity has $p<0.05$. Based on the results of the normality test, it is known that the scores for self-concept, gratitude, and malicious envy variables are normally distributed as shown by $p>0.05$. The results of the linearity test show that there is a linear relationship between the independent variables (self-concept and gratitude) and the independent variable (malicious envy) with the significance value of deviation from linearity is $p>0.05$. Based on the multicollinearity test, the Variance Inflation Factor (VIF) of the self-concept variable is 1.286, and the gratitude variable 1.286. It can be concluded that the assumption of no multicollinearity between the two independent variables is fulfilled as shown by the VIF less than 5 .

\section{Result and Discussion}

Based on the results of multiple regression analysis with two predictors using SPSS 21.0 for Windows, it was found that self-concept and gratitude are both negative predictors for 
malicious envy with $p=0.000(p<0.01)$ and a confidence level of $99 \%$. This shows that higher self-concept and gratitude of students means lower malicious envy. The coefficient of multiple determination of the constant of malicious envy is 0.291 (from Adjusted R Square). This shows that $29.1 \%$ of malicious envy is influenced by self-concept and gratitude while $70.9 \%$ is influenced by other factors, which should be investigated further to anticipate the emergence of malicious envy. These findings indicate that self-concept and gratitude are determinant factors and contribute to the level of malicious envy.

Besides, based on the multiple regression analysis, self-concept is not a negative predictor of malicious envy as indicated by $r=-0.098$ with $p>0.05$. A student's higher self-concept does not mean lower malicious envy. This indicates that students who have good self-concepts do not necessarily have low malicious envy and vice versa. It could be that students who have low self-concept have low malicious envy. Fuhrmann explains that self-concept is a person's basic concept about himself, his opinions and thoughts, understanding and awareness of who he is, the image of himself compared with others, and the idealism developed [10]. Students who have self-concept tend to define themselves by looking at social characteristics and comparisons. Social aspects are determinant in self-concept formation. Individuals are more likely to distinguish themselves from others in a comparative rather than an absolute manner [19]. This social comparison causes a person to end up with malicious envy. However, social comparison with gratitude for what is owned will greatly minimize malicious envy. This is evidenced by the findings which show that, if self-concept and gratitude are combined, they will result in low malicious envy of students with $p=0.000$. High self-concept and gratitude have a very strong influence on the level of malicious envy of students. If self-concept is not followed by gratitude, even though the student's self-concept is high, it does not guarantee the low or decreased individual malicious envy. This is partly due to the formation of self-concept containing social comparisons. Based on the results of data analysis, a regression equation line can be formulated : Malicious Envy $=71.903-0.062$ Self Concept - 0. 397 Gratitude.

The findings in this study support the previous study by Apple showing that social comparisons, especially those containing positive images of individuals toward others, can be fertile ground for envy or malicious envy. This social comparison and malicious envy can mediate depression. People often want attributes of others or even feel anxious and worried if the other person's attributes threaten the stability of his relationship with someone. Individuals compare their attributes with those of others. If they feel that other people's attributes are better and will threaten their relationship with others or their self-esteem, malicious envy will emerge [23]. This study also found that the gratitude obtains $r=-0.459$ with $p=0.000$ or $p$ $<0.01$, meaning that the gratitude variable is a negative predictor of malicious envy. Student's higher gratitude means lower malicious envy. The lower the student's level of gratitude is, the higher their malicious envy will be. The findings of this study support the study by Yanhui Xiang et al. showing that gratitude positively predicts benign envy and malicious envy. It also has a significant indirect effect on benign and malicious envy mediated by social support [11]. The findings of this study contribute to an effective strategy for preventing malicious envy by cultivating gratitude as an important aspect to minimize malicious envy. Malicious envy is an emotion that is oriented towards others but is a form of negative emotion that inhibits prosocial behavior and allows one to take actions that hurt and harm others, while gratitude can increase helping or prosocial behavior [11].

\section{Conclusion and Suggestion}


It is concluded that, first, self-concept and gratitude are negative predictors for malicious envy simultaneously. Student's higher self-concept and gratitude means lower malicious envy. Second, self-concept is not a negative predictor of malicious envy. Student's higher selfconcept does not contribute to lower malicious envy. Students could have high self-concept but high malicious envy, or vice versa. Third, gratitude is a negative predictor of malicious envy. Student's higher gratitude means lower malicious envy. Self-concept and gratitude are important aspects of minimizing the emergence of malicious envy simultaneously. Gratitude is also partially an important aspect of minimizing the growth of malicious envy.

For future researchers, it is recommended to further explore other factors that cause malicious envy, such as social environment, parenting, geographical area, and religious literacy and making adolescents and middle-aged adults as research subjects to comprehensively identify the factors that cause envy at all ages. For students, parents, and stakeholders, the results of this study can be a reference for developing character education and anticipating the emergence of malicious envy from an early age.

\section{References}

[1] N. Chou, H. T. G., \& Edge, "They are happier and having better lives than I am: The impact of using Facebook on perceptions of others' lives.," Cyberpsychology, Behav. Soc. Netw., vol. 15, no. 2, pp. 117-121, 2012.

[2] S. H. Smith, R. H., \& Kim, "Comprehending envy," Psychol. Bull., vol. 133, no. 1, pp. 46-47, 2007.

[3] Al-Ghazali, Mukhtashar Ihya Ulum al-Din, 1st ed. Beirut: dar al-Kutub al-Ilmiyyah, 2004.

[4] D. Carter and A. Rashidi, "Theoretical Model of Psychotherapy : Eastern Asian-Islamic Women with Mental Illness," Heal. Care Women Int., vol. 24, no. 5, pp. 399-413, 2010.

[5] K. Tai, D. J. Mcallister, and J. Narayanan, "Envy As Pain : Rethinking the Nature of Envy and Its Implications for Employees and Organizations," Acad. Manag. Rev., vol. 37, no. 1, pp. 107-129, 2012.

[6] N. Van De Ven, M. Zeelenberg, and R. Pieters, "Appraisal Patterns of Envy and Related Emotions," Motiv. Emot., vol. 36, no. 2, pp. 195-204, 2012.

[7] R. S. Lazarus, Emotion and Adaptation. New York: Oxford University Press, 1991.

[8] W. G. Parrott and R. H. Smith, "Distinguishing the Experiences of Envy and Jealousy," J. Pers. Soc. Psychol., vol. 64, no. 6, pp. 906-920, 1993.

[9] A.-I. A. H. M. bin M. Al-Ghazali, Ihya' Ulum Al Din, Jilid 4. Beirut: Dar Al - Kitab Al - Ilmiyyah, 1992.

[10] K. Rentzsch, M. Schröder-Abé, and A. Schütz, "Envy mediates the relation between low academic self-esteem and hostile tendencies," J. Res. Pers., vol. 58, no. October, pp. 143-153, 2015.

[11] Y. Xiang, X. Chao, and Y. Ye, "Effect of Gratitude on Benign and Malicious Envy : The Mediating Role of Social Support," Front. psychiatry, 9, vol. 9, pp. 1-7, 2018.

[12] R. A. Emmons and M. E. Mccullough, The Psychology of Gratitude. New York: Oxford University Press, 2004.

[13] N. M. Lambert, N. M. Lambert, and S. M. Graham, "A Prototype Analysis of Gratitude: Varieties of Gratitude Experiences A Prototype Analysis of Gratitude: Varieties of Gratitude Experiences," no. OCTOBER, 2009. 
[14] P. Fitzgerald, "Gratitude and justice," Ethics, vol. 109, no. 1, pp. 119-153, 1998.

[15] P. C. Watkins, Khathrane Woddward, T. Stone, and R. L. Kolts, "Gratitude and Happiness.Pdf," Social Behavior and Personality, vol. 31, no. 5. pp. 431-452, 2003.

[16] and R. N. Listiyandini, Ratih Arruum, Andhita Nathania, Dessy Syahniar, Lidwina Sonia, "Mengukur rasa syukur: Pengembangan model awal skala bersyukur versi Indonesia," J. Psikol. Ulayat Indones. J. Indig. Psychol., vol. 2, no. 2, pp. 473-496, 2015.

[17] S. Yulikhah, B. Bukhori, and A. Murtadho, "Self Concept, Self Efficacy, and Interpersonal Communication Effectiveness of Student," Psikohumaniora J. Penelit. Psikol., vol. 4, no. 1, pp. 65-76, 2019.

[18] J. W. Santrock, Life Span Development: Perkembangan Masa Hidup, 1st ed. Jakarta: Erlangga, 2002.

[19] R. J. Shavelson, J. J. Hubner, and G. C. Stanton, "Self-Concept: Validation of Construct Interpretations," Rev. Educ. Res., vol. 46, no. 3, pp. 407-441, 1976.

[20] P. B. Widodo, "Reliabilitas Dan Validitas Konstruk Skala Konsep Diri Untuk Mahasiswa Indonesia," J. Psikol. Univ. Diponegoro, vol. 3, no. 1, pp. 1-9, 2006.

[21] N. Rochmawati, Faktor Determinan Islamic Gratitude pada Mahasiswa. Yogyakarta: Disertasi Program Doktor UMY, 2019.

[22] N. Rochmawati, "Skala Envy," 169458, 2019.

[23] J. Appel, helmut; Gerlach, Alexander L.; Cruisius, "The interplay between Facebook use, social comparison, envy, and depression," Curr. Opin. Psychol., vol. 9, pp. 44-49, 2016. 